\title{
The Practices of Maleficium in English Literature
}

\author{
Shaymaa Fadhil Hasan ${ }^{1}$ \\ ${ }^{1}$ Department of English Language, Faculty of Humanities and Social Sciences, Koya University, Kurdistan Region, Iraq
}

\begin{abstract}
There is a long tradition among scholars to establish a link between the practice of black magic and culture. Black magic is seen as a category under which various beliefs and practices which are usually separated from religion and science are placed. These practices are most of the time associated with evil and demons. It has been observed that the role of black magic and witchcraft influenced Western societies to a large extent as it was not only the subject of literature but also of the interest to the whole society. Fears of witchcraft and black magic grew more intense and consequently led to "witch hunts" in many Western societies. In this paper, I argue that in English literature, the practice of black magic and witchcraft has been represented as a cultural practice. My paper provides a quick survey to trace back the practices of witchcraft in selected literary works from English literature. In my analysis, I focus of how the practice of black magic and sorcery is embedded within the texts to reflect people's obsession of it. For the sake of my argument, I will use the word "Maleficium" as an umbrella term to refer to all the practices, which include: Black magic, witchcraft, sorcery, necromancy, and voodoo.
\end{abstract}

KEY WORDS: Black Magic, Culture Practice, Literature, Maleficium, Sorcery, Witchcraft.

\section{THE PAPER}

The term "Maleficium" is a plural form for the word "maleficia" which comes from a Latin origin. The term "Maleficium" consists of two syllables maleficus+Ium, which means "An act of witchcraft performed with the intention of causing damage or injury" (Kierner, 2015, p. 19). It also refers to any act that involves evil deeds or practices of black magic, sorcery, and witchcraft (Petersen, 2009, p. 220). The results of such practices are usually evil and they may cause harm to people and their properties. The aim of this research is to examine how the practices of maleficium are reflected in selected works from English literature. In the following account, I

Koya University Journal of Humanities and Social Sciences (KUJHSS),

Volume 3, Issue 1, 2020.

Received 12 June 2019; Accepted 21 June 2019,

Regular research paper: Published 22 June 2020

Corresponding author's e-mail: shaima.fadhil@koyauniversity.org

Copyright (C2020 Shaymaa F. Hasan. This is an open access

article distributed under the Creative Commons Attribution License. start with a general introduction of the term and its implications, such as the practices of sorcery and malicious black magic, which are considered as vital practices in many countries all over the world. The fact that how these practices are related to human conflicts and their attempts to possess supernatural power to enable them to have control over other people and their possessions is also visited in this paper. Maleficium appears as the main theme when it is concerned with misfortune, harm, accusation, blame, and risk. Therefore, it is often seen as a form of social control as well as a way of achieving superiority over others. Maleficium is described as a term that explains how humans interact with magic, such as sorcery and witchcraft. Sorcerers and witches appear in an extraordinary harmony among worldviews that posit the existence of magic. Sorcerers take the role of magic practitioner who engages in activities often seen by others as magic practiced for evil purposes.

As far as English culture and literature are concerned, black magic and sorcery seem to live at the heart of the English identity and culture. According to some scholars, the practice of sorcery and magic is called "the perfect knowledge of natural things" and those who 
practice it is known as magicians by modern scholars. The Latin calls them wise-men and the Greek call them philosophers (Traister, 1984, p. 1-31). There are two sorts of magic: The first magic is natural; which all excellent wise men do admit and admire. It is considered a safe type of magic and causes no harm such as the mountebanks who practice it for healing purposes (Summers, 1946, p. 25). The second type of magic is notorious and scandalous because it has to do with evil spirits, and consists of enchantments and wicked curiosity. It is called sorcery, which stands merely on fancies and imaginations. In my paper, I deal with the latter as it involves negative practices for evil purposes.

Witchcraft or witchery is the practice of magical skills which are done by certain groups of people. Beliefs in witchcraft are always present within societies whose cultural framework includes a magical world view. Historically, the predominant concept of witchcraft in the Western world is derived from Old Testament laws against witchcraft. They entered the mainstream when these beliefs in witchcraft gained Church approval in the Early Modern Period. It reflects an eternal conflict between good and evil. Witchcraft is generally seen as evil and always connected to the devil and devil worships (Russell, 2013, pp. 4-10). Although the practice of witchcraft can be performed by both male and female, it is usually connected with females. Women during ancient times were considered powerful and mysterious and they used their spells to control nature and cause chaos. The women who do magic were always treated as of a lower status unlike the male sorcerers who were considered educated and of a high status. The general belief among people was that witches were worshiping the devil to whom they gave up their souls and gained some special skills in return. They often "gain" ${ }^{1 "}$ a spirit in a form of a black cat or a black dog which was known as "familiar spirits" or "animal guides" (Tyson, 2004, p. 25). On top of that, people believed that witches attended wild celebrations of Sabbath in a company of the devil, their master, whom they vowed their devotion. The practice of witchcraft is attended with celebrations that involve dancing and spiritual ceremonies (Waite, 2006, p. 20). Religiously speaking, the Bible, according to some scholars, speaks of witchcraft (Henry and Adams, 1889, pp. 213-217). In both Old and New Testaments, there are many indications about how witchcraft and involvement with evil can be hazardous. During 6th and 7th centuries, the church acted against witchcraft and sorcery violently. Those who practiced it were generally treated as heretics. In England, the first trials against witches took place during 12th century (Henry and Adams, 1889, pp. 209-210). The cases often depicted accusations of sorcery, questionable practices, and evoking spirits. All these mentioned cases were treated as acts against God. Later, in the Elizabethan period, there was a strict legal prosecution against witchcraft. The general belief in witchcraft and similar practices contributed to the overall atmosphere in the society (Ford, 1982, p. 15).

It is interesting to investigate why sorcery and black magic have such a profound hold over the popular imagination. It is like a game of chess, and as any good player knows, the strategies of chess are as relevant in the real world as on the playing board (Walter, 2012, p. 2-3). The Book of English Magic by Philip Carr Gomm and Richard Heygate offers a thorough history of magic and magicians in England. It reveals a 5000-year tradition of English magic, stretching from the Anglo-Saxons until the modern age (Carr Gomm and Heygate, 2009). The Book of English Magic draws a link between fictional and historical figures that have influenced and shaped the history of English magic. For example, the legendary wizards from Merlin to Harry Potter who have shaped the English perceptions of magic along with John Dee a mathematician, astrologer, occultist, and consultant to Queen Elizabeth I - who like Crowley and other magicians initiated a powerful fiction around the cult of their personality. Writers and artists who have drawn on magic as inspiration for their works of art like WB Yeats were fascinated by the world of the occult.

As far as the English culture and literature are concerned, the road map of "maleficium" started during the medieval period. Witches and magical powers became a subject of many legends and folktales such as the Arthurian legends. For example, in the tale of Sir Gawain and the Green Knight, there is an explicit reference to the practice of maleficium performed by Morgan Le Fay. In her article "Morgan Le Fay: The Inheritance of the Goddess," Anna Rita Martins discusses the character of Morgan Le Fay as a witch who practices magic and witchcraft to serve her thirst for power (Martins, 2015). Morgan is the older half-sister of King Arthur and the daughter of Queen Igerna and Gorlois. She represents the "evolving understanding of the demonic witch and her diabolical practice of maleficium" (Oliver, 2015, p. 38). She is the powerful sorcerous and a treacherous foe in the Arthurian legends. It is believed that the main reason behind Morgan's practice of witchcraft is to achieve revenge from Queen Guinevere. Both of them were rivals for the love of Arthur's most close and preferred knight, Sir Lancelot. Morgan felt jealous and therefore wanted to cause harm to the queen by sending the Green Knight to the court to frighten the queen to death. The character of Morgan Le Fay is adapted from Celtic legends where the Celtic goddesses Morrígan or Welsh Modron was established as an enchantress and shapeshifter (Martins, 2015). Morgan cannot be trusted and easily disguises herself to achieve her own purposes. She can change her appearance, becoming old, young, beautiful, or ugly at her will. Morgan Le Fay 
brings to Arthurian legend what every good story needs which are the mystique and the possibility of danger. Morgan represents the "beautiful evil" and the "yearned-after desire" that can perish and destroy anything that stands in her way. The presence of Morgan provides a strong Celtic source of storytelling magic, from which other villains spring (Martins, 2015, p. 159). The character of Morgan changed due to the medieval perception of magic in relation to women, as they were often believed to be practicing black magic. She is described by Arthur's nemesis as an evil woman and "uncontrollable:"

She has acquired deep learning, hard-won skill, many of the masteries of Merlin; for she has at times dealt in rare magic with that renowned clerk, who knows all your nights at home. Morgan the goddess is therefore her name; no person is so haughty but she can tame (Sir Gawain and the Green Knight, stanza 19).

The above-mentioned quotation shows that Morgan learned the practices of witchcraft and maleficium from Merlin, the very famous wizard and sorcerer. Merlin is a man of mystery and magic; he wore many hats; he was a sorcerer, a prophet, a bard, an advisor, and a tutor. The poem heavily projects scenes of sorcery and supernatural events. The appearance of brave knights supported by witches and sorcerers is considered part of everyday culture of the English society (Loomis, 1936, p. 99). As far as Morgan's practices of black magic are concerned, they are mainly performed through a series of illusions to create a variety of effects. One of Morgan's demonic magic is the transformation of Bertilak into the fearful figure of the Green Knight to achieve her goals of frightening the queen and to humiliate Arthur's court. Choosing the green color is very significant; according to the British folklore, the devil is thought to be green. Moreover, the green color is also known to have signified the act of witchcraft, devilry, and evil (Oliver, 2015, p. 52). Another practice of witchcraft is the green girdle which is given to Gawain to make its wearer invincible as it has magical power, "I shall give you my girdle that will enrich you less" (Sir Gawain and the Green Knight, stanza 28). The girdle is described as "a droned with green silk and ornamented with gold" (Sir Gawain and the Green Knight, stanza 28). The girdle can be seen as a product of Morgan's witchcraft; it has magical power and protective power. Morgan describes the girdle as a simple thing that has great power: "Whoso knew the virtues that are knit therein, he would esteem it at a greater price peradventure; for whatsoever man is girt with this green lace, whereas he has it fittingly wrapped about him, there is no warrior under heaven that can wound him; for he could not be slain by any device in the world" (Sir Gawain and the Green Knight, stanza 29).
During the sixteenth century, authors continue to portray the changes of society and how magic played a great dominant role during that period. The role of magic and the supernatural in the Elizabethan era is undeniable. The belief in alchemy and astrology was present in the society since the fourteenth century, and it persisted till the time of Renaissance. The Renaissance period in England is considered as the "witch mania" period (Yehuda, 1980, p. 8). People were obsessed by the idea of magic and playwrights such as Shakespeare I. p. 41-48, (Marlowe pp. 47-50), and Ben Johnson excelled in producing plays rich in sorcery and magic topics. The occultism influenced many aspects of life and its features are also present in works of those authors. For example, Boris Ford, in his book The Age of Shakespeare, claims that the time of Renaissance was a crucial time in which the obsession in black magic increased among people (Ford, 1982, p. 15). Although science and education were developing, the role of magic, alchemy, astronomy, and witchcraft was in great function (Yates, 2004, p. 87). The strong belief in the supernatural that was present in society may have contributed to the fact that the Elizabethan era was to a great extent influenced by occultism which left its trace on philosophy, science, and in literature. The Renaissance culture presented witches as having marks of the devil and they must pass certain tests to prove their innocence. Sometimes, these ladies were obliged to practice magic asking for food and clothes. Some of them were forced to admit that they are witches in fear for their lives (Levin, 2016, pp. 5-6). A closer look on Shakespeare's contemporary playwrights dealing with the theme of witchcraft was taken. The characters of witches and sorceresses appear in the Elizabethan plays more often. Frances Yates notices a figure that influenced the Elizabethan era, John Dee, an occult philosopher and mathematician that was affected by Neoplatonism. He gained a great importance, having patrons in noble families; Dee was even in the service of Queen Elizabeth herself. Besides, he was interested in alchemy and was inspired by Cornelius Agrippa ${ }^{2}$ (Yates, 2004, p. 88). According to Davenport Adams, Dee believed that he could foretell the future from his dreams and that he could see spirits, such as angels, and he was able to communicate with them. These apparitions showed up in his magical mirror, always through a medium, which Dee called a "skryer." Dee himself was an observer who interprets the meanings of such apparitions. Edward Kelly was one of Dee's mediums. He was a magician and a swindler who did not hesitate to break the laws. With Kelly as a medium, Dee's magic mirror worked perfectly. Dee's collaboration with his "skryer" is regarded to be "the initial product of spiritualism in English literature" (Henry and Adams, 1889, pp. 84-90). Although John Dee was an influential 
figure, there were also many charlatans who were considered by philosophers as being able to tell the future.

Stories about magicians and fairies were very popular during the Renaissance period. Many of the plays written during this time have references to the practices of witchcraft and black magic. Marlowe's The Tragical History of the Life and Death of Doctor Faustus and Shakespeare's Macbeth are good examples of the manifestation of maleficium and its practices. These plays are regarded as the most effective plays in which the influence of sorcery on the common people was reflected. The interest in necromancy and the rising of spirits are considered as hot topics as theaters became filled with ghosts, witches, and devils. In these plays, the practice of maleficium can be seen as a cultural activity performed by the main characters to possess supernatural power so as to achieve forbidden desires. The main characters of the plays are known as "practicing magicians" as they are interested in philosophy, alchemy, astronomy, and necromancy (Herrington, 1919, p. 458). Their profession of necromancy involved long professional study of magic. They also had to sign a pact with the devil through which they had to give up their souls to the devil to handle the black magic to gain their abilities and skills. The plays show that the use of dark powers always carries certain risk of dangerousness which turns into the bad ending for the characters (Herrington, 1919, p. 458). The following section provides analysis of the selected plays from the Renaissance period where the practice of maleficum is seen as a cultural activity.

To start with Christopher Marlowe's The Tragical History of the Life and Death of Doctor Faustus, the play offers a significant example of the practice of maleficium. The play was written between 1588 and 1589. Maleficium is practiced by the main character Dr. Faustus who strikes a deal with Lucifer by which he gets Mephistopheles as a personal servant who fulfills whatever Faustus wishes. Christopher Marlowe's Doctor Faustus demonstrates a carnival of Black Magic and necromantic practices. From the first performance of the play, the English audience found it interesting and attracting. Faustus had a deal with the devil to prosper and be famous in his life, so, he sold his soul to the devil. The play is entirely full of light and magical images that make the audience on alert and terrified on the same time. Faustus seeks to connect with ancient history to revolutionize himself as an individual. By conjuring up ancient mythological history and facilitating the physical manifestation of it through Black Magic. Faustus seeks to reconstruct the domain of the old gods around him, deifying himself as the figure of power in a present that he has manufactured from the past. The tool with which he seeks to achieve this ascendancy is magic, which he recognizes as being able to guarantee him with seemingly divine powers. Faustus desires for the metaphysical powers are a never-ending thirst. He explicitly refers to that when he claims that "this metaphysics of magicians/and necromantic books are heavenly... Aye, these are those that Faustus most desires" (Doctor Faustus, I. 47-50).

In Scene three, Faustus appears standing in a magic circle which is marked with different signs and he chants Latin words. He tries to conjurer and raises the spirit of Mephistopheles from the dead. He admires his own abilities and shows his egocentric personality as it is explained in the following extract:

Faustus, begin thine incantations,

And try if devils will obey thy hest,

Seeing thou hast pray'd and sacrific'd to them.

Within this circle is Jehovah's name,

Forward and backward anagrammatiz'd,

The abbreviated names of holy saints,

Figures of every adjunct to the heavens,

And characters of signs and erring stars,

By which the spirits are enforced to rise:

Then fear not, Faustus, but be resolute,

And try the uttermost magic can perform. -

Sint mihi dei Acherontis propitii! Valeat numen triplex

Jehovoe!

Ignei, aerii, aquatani spiritus, salvete! Orientis princeps

Belzebub, inferni ardentis monarcha, et Demogorgon,

propitiamus

vos, ut appareat et surgat Mephistophilis, quod tumeraris:

per Jehovam, Gehennam, et consecratam aquam quam

nunc spargo,

signumque crucis quod nunc facio, et per vota nostra, ipse nunc

surgat nobis dicatus Mephistophilis!

(Dr. Faustus, III.5-15)

This scene is an illustrative example of the practice of magic and witchcraft. The ceremonial rituals open with Faustus reading certain incantations to conjure Mephistopheles to put him under his service. Mephistopheles will not obey Faustus unless he sells his soul for Lucifer. Eventually, Faustus signs the famous pact with the devil as he agrees to worship Lucifer. In return, Faustus is going to have whatever he wants as Faustus says:

"To give me whatsoever I shall ask, To tell me whatsoever I demand, To slay mine enemies, and to aid my friends, And always be obedient to my will" (Dr. Faustus, IV, pp. 95-98).

Another practice of magic can be found in scene five when Faustus decides to make a deal with Lucifer through stabbing his arm to write the deed in blood:

Lo, Mephistophilis, for love of thee,

I cut mine arm, and with my proper blood

Assure my soul to be great Lucifer's, 
Chief lord and regent of perpetual night!

View here the blood that trickles from mine arm

And let it be propitious for my wish.

(Dr. Faustus, V. 53-58)

Another writer whose works show the interest in maleficium is William Shakespeare. The author lived amidst all the supernatural phenomenon infatuation and witch hunting chaos, which had clear influence on his drama. Shakespeare's use of magic, witchcraft, and mystical elements contribute meaningful purpose to his works. Black Magic and superstitious themes function as vehicles to express the beliefs and the culture of sorcery of the English during that time (Petsche, 2011, 2-3). In Shakespeare, the practice of magic was known as "mischief following anger, and it was one of the most common charges against suspected witches in cases brought to trial" (Levin, 2016, p. 2). Poor, old, and widowed women were usually accused of practicing sorcery for the sake of getting "angry revenge" as they are refused to be given food or drink. In case a misfortune happens to a person who did not give these old women a food or drink they were usually blamed for it and consequently put into trial (Levin, 2016, p. 4).

A good example can be found in Macbeth where in Act one, Scene three where the first witch tells her sisters that once she saw a woman eating chestnuts she demanded some, but the woman called her "witch" and ordered her away. The first witch then planned to harm the woman's husband. The three witches, therefore, cast a spell or "charm" in vengeance (1.iii.37). The trials of witchcraft were famous during the reign of the King James of Scotland (1566-1625) who became greatly convinced about the evils of sorcery and witchcraft and their great danger to him. This had led to the series of trials which began in 1591. According to Traister, King James believed that a group of powerful witches made a deal with the devil to kill him by practicing sorcery. To document these trials, James published a study of witchcraft that he called Demonology and the book was published in London (Traister, 1984, p. 15). It is believed that the king's obsession with witches and sorcerers had an influence on Shakespeare's Macbeth. As some critics argue, Shakespeare wrote his play to satisfy his king (Levin, 2016, pp. 5-6).

Shakespeare's Macbeth (c. 1605) is another example of the manifestation of maleficium. The play is regarded as one of the famous plays that tackled the theme of the evils of witchery and Black Magic. The play is about ambition, sorcery, treachery, murder, and revenge. It is a dark and mysterious work which serves as an open door to look at the society and the mood of England during its composition. The main practice of witchcraft is performed by the three witches who are ruled by Hecate $^{3}$ who appears in the play as the leader of the weird sisters. The play opens with a ceremonial witchery gathering of the three witches who seem to end their meeting and planning for the next. Having Macbeth as their future victim, they hear voices of "familiars" who take the form of a cat (Graymalkin) and a toad (Paddock). This scene prepares for the practice of maleficium which is performed in the play. The appearance of the witches set the negative mood of the play; their role in the play serves two main functions. They project the supernatural element of the play which elaborates its theme. They also function as instruments of fate through delivering their prophecies to Macbeth who is then motivated to chase his ambition of being a king. Moreover, the playsets forth the Elizabethan belief that women become witches through accepting to have sexual intercourse with the devil or other evil spirits.

The other practice of witchcraft in the play can be traced back to Lady Macbeth's summoning up demonic spirits to help her carry out her plan to overthrow the power of King Duncan. She appears in Act One Scene five speaking to the evil spirits to fill her with cruelty and gut which are necessary for her to act violently. In this scene, Lady Macbeth is "acting like a conjuring witch who wants to reach out to the forces of darkness" to aid her in her evil mission. She invokes the evil spirits to provoke Macbeth to kill Duncan:

Come, you spirits

That tend on mortal thoughts, unsex me here

And fill me, from the crown to the toe, top-full

Of direst cruelty! Make thick my blood,

Stop up the access and passage to remorse,

That no compunctious visitings of nature Shake

my fell purpose nor keep peace between The effect and it!

(Macbeth, I. V.41-48)

In this play, the wired sisters or the three witches are considered dangerous and capable of doing evil. The practice of magic is described in detail; they are depicted as preparing a fearful scene of witchcraft. They are fully engaged with ugly rituals; they are surrounded by their familiars: "the brindled cat," "hedge-pig," and "harpier." They stir fragments of different creatures that are associated with night time and black magic (Rosenberg, 1978, p. 25). As they stir the mixture which includes pieces of reptiles, wolf, shark, goat, tiger, baboon, and human body parts, they utter their spells: "Double, double, toil, and trouble; Fire burn; and Cauldron, bubble" (Macbeth, IV. I. 10-11). The repetition of the incantation is meant to show the complicated ceremony to conjure up "a Charm of powerful trouble." Some of the conversations of the weird sisters would have seemed common and familiar to Shakespeare as a person living during that age (Tonge, 1932).

In Act four, Macbeth himself yields to his evil desires and begins seeking the support of the three witches. 
Macbeth visits the three witches because he needs to know more about the future. He considers them the embodiment of supernatural power that would provide him with whatever Black Magic can provide. He appeals to the three witches to perform their unlawful magic:

I conjure you, by that which you profess,

Howe'er you come to know it, answer me:

Though you untie the winds, and let them fight against churches...

Though the treasure of nature's germens tumble all together, Even till destruction sicken; answer me To what I ask you.

(Macbeth, VI. I. 50-60)

This extract shows that Macbeth believes in witchcraft and his appeal to the three witches suggests that "he is conscious that he sacrifices something in himself by appealing to them" (Tonge, 1932, p. 242).

The seventeenth and the eighteenth centuries witnessed a deviation from sorcery and black magic practices toward supernatural and spiritual phenomena.

England witnessed some sort of a contradiction. With the emergence of the industrial revolution which modernized the world in accordance with the new scientific inventions, practices like sorcery and witchcraft, still found a place and were considered extremely popular during these remarkable centuries. It was a golden age of belief in supernatural forces, energies, ghost stories, and strange phenomena (Luckhurst, 2014, pp. 2-3). Mesmerism was one of most famous spiritual practices during that period. The Mesmerist would throw his subject into a deep sleep, allowing the transmission of energy into the weaker body of his patient to recharge their battery (Luckhurst, 2014, pp. 2-3). It functions as a medical cure by manipulating the invisible flows of "animal magnetism" that passes through and between bodies (Christian and Mesmer, 2011, pp. 9-10). Another movement that caught people's attention during that period was the powerful appearance of mediums. Mediums were often women because they were considered to be more delicate and having a sensitive nervous system than men. There were few examples of men mediums such as the famous D. D. Home (1833-1886) who is believed to inspire Robert Browning Mr. Sludge, "The Medium" (1864). Although communication with spirits was strictly forbidden in the Bible, this practice became a popular form of dissenting belief (Luckhurst, 2014, p. 8). As far as my paper is concerned, these movements do not fall within the scope of maleficium as they belong to the world of the supernatural powers which were clearly manifested through the literature of the period. Writers like Catherine Crowe, Vernon Lee, and Margaret Oliphant show their interest in the world of the supernatural by writing stories about the dead and ghosts (Luckhurst, 2014 , p. 4). Since my paper is only concerned with practices of witchcraft and sorcery, I prefer not to deal with practices of mesmerism and mediums as they are mainly concerned with spiritual experiences.

The Nineteenth-century witnessed the revival of the cult of maleficium after a period of recession during the Eighteenth century. The age's obsession in witchcraft and magic is clearly reflected in Nathaniel Hawthorne's The Scarlet Letter. The book provides evidence of the practice of witchcraft and black magic. It shows the extreme indulgence of the puritans in such practices. The novel provides an image of the practices of sorcery in Salem Massachusetts. It alludes to the public execution of witches that was at its peak. Witches were not allowed to meet in public; therefore, all their meetings were held under supreme secrecy. The people of Salem Massachusetts strongly believed that those who are involved in sorcery or witchcraft practices should be sentenced to death as they are accused of corrupting the Christian Religion (Wentersdorf, 1972, p. 134). The deep dark woods of Boston witness the practices of the "Black Man" and the gatherings of the witches who prove to be evil and dangerous. The whole story is based on supernatural images and evil symbolism. The novel sheds some lights on people's belief in witchcraft and sorcery as they gossip about the Black Man's necromancy. The act of witchcraft is performed mainly by the Black Man (Chillingworth) and the witch-lady (Mistress Hibbins) who is believed to be an official witch. To some critics, "the witch, the Black Man, the forest, and the midnight ceremonies said to be performed there" stand for the rituals of Black Magic practiced by some inhabitants of Salem (Wentersdorf, 1972, p. 133). The secret gathering is narrated by Pearl to her mother, she told her that "a thousand and a thousand people had met him here (dark forest), and had written in his book, and have his mark on them. And that ugly-tempered lady, old Mistress Hibbins, was

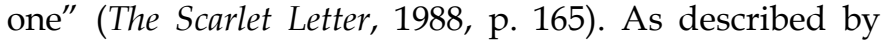
Hawthorne, mistress Hibbins is the "Governor Bellingham's bitter-tempered sister, and the same who, a few years later was executed as a witch" (The Scarlet Letter, 1988, p. 104). As a part of her secret profession as a witch, Hibbins used to meet the Black Man (Devil) at night time in the deep dark woods. She tries to drag the heroine Hester Prynne to their meetings as she invites Hester "Wilt thou go with us tonight? There will be a merely company in the forest; and I will nigh promised the Black Man that comely Hester Prynne should make one" (The Scarlet Letter, 1988, p. 104). The novel also marks a pact with the devil scene where the Black Man "haunts the forest, and carries a book with him - a big, heavy book, with iron clasps; and how this ugly Black Man offers his book and an iron pen to everybody that 
meets him here among the trees; and they are to write their names with their own blood. And then he sets his mark on their bosoms!" (The Scarlet Letter, 1988, p. 165). The ceremonial practice of signing the book with their blood is so famous in the cult of maleficium. The act of signing is symbolic; it represents their pact with devil. For those who signed their names in his book were mainly thinking "to avail themselves of his services and would consent to practice his dark arts on their behalf" (Wentersdorf, 1972, p. 143). Although Hester did not sign her name in the Black Man's book, she had a verbal pact with him not for a personal gain. According to some critics, Hester sells her soul to the Black Man to save her life and the life of her secret partner, Arthur Dimmisdale. She regrets her deal with the Black Man as she was forced to do; she tells the Black Man "Hast thou enticed me into a bond that will prove the ruin of my soul?" (69).

The Victorian literature reflected a deep interest in the ghost stories. The recurrent appearance of fairies, witches, and ghosts was greatly admired by the Victorian audience. People believed in the existence of ghosts and it was part of their religious education. They had a strong belief that the mortal world is haunted by two types of ghosts: The good and the evil. They were preoccupied with the ideas of death and life after death. Examples of some popular ghost stories at that time: "The Old Nurse's Story" (1852) by Elizabeth Gaskell, "The Signal Man" (1866) by Charles Dickens, and The Uninhabited House (1875) by Charlotte Riddell (Flint, 2014, p. 35).

The obsession in Black Magic practices reaches the modern world with new shapes and techniques. With the great advances in science come great advances in the field of black magic and sorcery. Modern literature projected a deep influence in magic, especially the African Voodoo practices. The famous voodoo doll with its creepy figure that stands for real persons shows how the magician pin it several times with a sharp needle to inflict deep pain in that person. It is used by people to achieve certain purposes, such as harming others due to jealousy or hatred. The form of the voodoo doll, as it is most commonly understood, is based on a magical practice that historically derived from Europe rather than Africa or America. Although it comes in various different forms, such practices are found in the magical traditions of many cultures across the world (Armitage, 2015, p. 85-88). In some other cultures, the Voodoo doll can be used to break the bewitchment rather than inflicting pain on others. For example, there are textual records attest to the fact that certain cunning folk in Britain made dolls of a witch out of rags and other materials and then pierced them with pins with the intention of inflicting physical harm on the witch and breaking their bewitchment (Hutton, 1999, p. 96).

Thomas Hardy's (p. 230) novel The Return of the Native provides a good example of a superstitious and paganistic aspect of rural England. The Voodoo doll is practiced by Susan Nunsuch; it is commonly employed to describe an effigy into which pins are inserted (Armitage, 2015, p. 85). She makes a Voodoo doll that stands for Eustacia Vye, the beauty queen of the Heath. She tries to cause harm to Eustacia thinking that she has inflicted some certain disease on her boy (Paterson, 1960, p. 5-6). She started molding a figure of humans from wax by warming and kneading, cutting and twisting, dismembering, and re-joining the incipient image. She had in about a quarter of an hour produced a shape which tolerably well resembled a woman and was about six inches high. She laid it on the table to get cold and hard. Meanwhile, she took the candle and went upstairs to where her little boy was lying:

"Did you notice, my dear, what Mrs. Eustacia wore this afternoon besides the dark dress?"

"A red ribbon round her neck."

"Anything else?"

"No-except sandal-shoes."

"A red ribbon and sandal-shoes, she said to herself."

(The Return of the Native, p. 230).

Susan Nunsuch starts thrusting pins into the doll murmuring strange words from the Lord's Prayer and she repeated them backwards. Susan uttered the lugubrious discourse 3 times slowly, and when it was completed the image had considerably diminished. As the wax dropped into the fire a long flame arose from the spot, and curling its tongue round the figure ate still further into its substance. A pin occasionally dropped with the wax, and the embers heated it red as it lay. The novel ends with Eustacia committing suicide by throwing herself into swollen stream. Some critics argue that the act of suicide took place after the voodoo practice; this suggests that Eustacia was cursed by the practices of voodoo which performed by Susan Nunsuch (Powell, 1965, p. 218). Suzan Nunsuch believes that Eustacia is a witch; therefore, she practices voodoo to break the bewitchment of her son.

\section{CONCLUSION}

The belief in Maleficium with its connotations such as Black Magic, sorcery, and witchcraft can be traced back to classical antiquity and has a continuous history during the Middle Ages, sustained in witch hunts and giving rise to the fairy tale and popular culture. Since classical times, people practiced magic not only to harm those they hate but also to deprive them of their lands and properties and this type of magic can labeled as Satanic or Black Magic. In England, the practices of 
Black Magic were mainly considered as a female pursuit and connected to Maleficium. Literature is a great medium to introduce readers to such worlds and practices; it shows how people were preoccupied with the ideas of Black Magic and sorcery. People are attracted to the unexplained scenes of conjuring evil spirits and love to wonder about mixing magical potions to terrify people and make them wonder their credibility.

\section{REFERENCES}

Adams, W.H.A. (1889) Witch, Warlock, and Magician: Historical Sketches of Magic and Witchcraft in England and Scotland. London: Chatto and Windus.

Armitage, N. (2015) European and African figural ritual magic: The beginnings of the voodoo doll myth. In: Houlbrook, C. and Armitage, N., (eds.), The materiality of magic: An artifactual investigation into ritual practices and popular beliefs. Oxford: Oxbow.

Boris, F. (1982) The age of Shakespeare: The new pelican guide to English literature. Vol. 2. London: Penguin.

Carr-Gomm, P. and Heygate, R. (2009) The book of english magic. New York: Overlook Press.

Christian, W.K. and Mesmer, F.A. (2011) Mesmerismus: Oder, system der wechselwirkungen, theorie und anwendung des thierischen magnetismus als die allgemeine heilkunde zur erhaltung des menschen in German, facsimile of the. Cambridge: Cambridge University Press.

Flint, K., (ed.). (2014) The Cambridge history of Victorian literature. Cambridge: Cambridge University Press.

Herrington, H.W. (1919) Witchcraft and magic in the Elizabethan drama. The Journal of American Folklore, 32, pp. 447-485.

Hutton, R. (1999) The triumph of the moon: A history of modern pagan witchcraft. Oxford: Oxford University Press.

Karl, W. (1972) The element of witchcraft in the scarlet letter. Folklore, 83(2), pp. 132-153.

Kierner, C.A. (2015) Virginia women: Their lives and times. Athens, GA: University of Georgia Press.

Lauren, W. (1987) History of the concept of empathy. In: Eisenberg, N. and Strayer, J., (eds.), Empathy and Its Development. Cambridge: Cambridge University Press.

Levin, C. (2016) Witchcraft in Shakespeare's England. Manchester: The British Library.

Marlowe, C. (1892) Tragical history of Dr. Faustus: Greene: Honourable history of friar bacon and friar Bungay. Princeton University: Clarendon Press.

Paterson, J. (1960) The poetics of the return of the native. Modern Fiction Studies, 6(3), pp. 214-222.

Petersen, J.A (2009) Contemporary religious Satanism: A critical anthology. Cheltenham: Ashgate Publishing, Ltd.

Petsche, S. (2011) Something wicked this way comes: Witchcraft in Shakespeare's Macbeth and the connection to Elizabethan England. England: Stephanie Petsche.

Powell, P.H. (1965) On teaching the return of the native. The English Journal, 54(3), pp. 217-222.
Richard, M.G. (2006) Encyclopedia of witchcraft: The Western tradition. Santa Barbara: ABC-CLIO.

Rosenberg, M. (1978) The masks of macbeth. Berkeley: University of California.

Russell, J.B. Witchcraft-Encyclopædia Britannica. Available from: http:/ / www. Britannica.com. (Accessed: 29 June 2013).

Shakespeare, W. (1965) Macbeth. Harlow: Pearson Education Limited.

Summers, M. (1946) Withcraft and black magic. London: Courier Dover Publications.

Thomas, H. (2012) The return of the native. New York: Cornell University.

Tonge, M. (1932) Black magic and miracles in macbeth. The Journal of English and Germanic Philology, 31(2), pp. 234-246.

Traister, B.H. (1984) Heavenly necromancers: The magician in english renaissance drama. Columbia, MO: Missouri Press.

Tyson, D. (2004) Familiar spirits: A practical guide for witches and magicians. Minnesota: Llewellyn Worldwide.

Waite, A.E. (2006) The book of black magic and ceremonial magic. California: The Book Tree.

Walter, D. (2012) Why English culture is bewitched by magic. Fantasy books. The Guardian. Newspaper.

Yates, F. (2004) The occult philosophy in the Elizabethan age. New York: Routledge.

Yehuda, N.B. (1980) The European witch craze of the 14th to 17th centuries: A sociologist's perspective. American Journal of Sociology, 86(1), pp. 1-31.

1 The term 'gain' here implies the idea of having a spirit under the service of his/her owner.

${ }^{2}$ Cornelius Agrippa was a German physician and an occult writer.

${ }^{3}$ In the Greek mythology, Hecate was the goddess of magic, witchcraft, the night, moon, ghosts and necromancy. She is the ruler of the three witches in Macbeth. 